\title{
ШВЕДСЬКА ДЕРЖАВА ДОБРОБУТУ В ОБ'ЄКТИВІ УКРАЇНСЬКОЇ ЕМІГРАЦІЙНОЇ ПЕРІОДИКИ МІЖВОЄННОГО ЧАСУ
}

\author{
олеся Коваль \\ Вінницький державний педагогічний університет ім. М. Коцюбинського \\ (Вінниця, Україна) \\ e-mail: koval.vinhistory@gmail.com \\ ORCID: https://orcid.org/0000-0002-0703-6490
}

\begin{abstract}
У даній статті висвітлюється держава добробуту у Швеції (питання економіки, політики, військової та гуманітарної сфер) на сторінках української еміграційної преси 1926-1939 рр. У дослідженні аналізуються матеріали авторитетних видань міжвоєнного часу - тижневика «Тризуб/Le Trident» (Франція) та газети «Свобода/Svoboda» (США), визначаються спільні та відмінні риси у позиціонуванні теми, ступінь зацікавленості скандинавськими питаннями та актуальність публікацій у колах українців на еміграції в Європі та Америці.
\end{abstract}

Ключові слова: держава добробуту, Швеція, Тризуб, Свобода, українська еміграція

В умовах реалізації реформ в Україні, які часто носять половинчастий характер за змістом і не мають чіткої довгострокової стратегії, актуальним стає пошук ефективних моделей державного управління з метою забезпечення економічної та політичної стабільності, суспільної згоди. За цих обставин перед дослідниками постає завдання вивчення історичного досвіду у питаннях сталості національної моделі соціальної держави, якою Україна $є$ і прагне бути згідно ст. 1 Конституції України. Одним із найуспішніших кейсів держави добробуту XX ст. $є$ Шведське королівство, що до сьогодні зберігає високий рівень загального добробуту та соціальної гармонії, налагоджені правові механізми договірних відносин. Після поразки Української революції активний моніторинг успішних європейських державних програм залишався в полі зору української еміграції. Свідченням цього $є$ періодичні видання, на шпальтах яких відображено чіткий спектр актуальних тем, серед яких - держава добробуту у Швеції.

Заявлена тема $є$ новим поглядом на питання українсько-шведських взаємин міжвоєнного часу та недослідженим питанням української історіографії. Проміжні результати дослідження заявленої проблеми були частково висвітлені дослідницею О. Коваль ${ }^{1}$ у співавторстві з П. Кравченком ${ }^{2}$ на міжнародних наукових конференціях у 2020-2021 рр. Дана наукова стаття подає розширений зміст проблеми. Авторка сконцентрувала увагу на спільних і відмінних рисах у позиціонуванні

\footnotetext{
${ }^{1}$ Коваль О. Шведська держава добробуту в українській еміграційній пресі міжвоєнного періоду (на прикладі газети «Свобода», США) // Суспільні науки: виклики і сьогодення: матеріали Міжнародної науково-практичної конференції (м. Одеса, Україна, 12-13 червня 2020 р.). Одеса, 2020. C. 24-29.

2 Коваль 0., Кравченко П. Шведське політичне та культурне життя на шпальтах української еміграційної преси міжвоєнного часу (на прикладі тижневика «Тризуб/Le Trident», Франція) // The IV International Science Conference "Prospects and achievements in applied and basic sciences», February 9-12, 2021, Budapest, Hungary. P. 193-196.
} 
шведської теми на сторінках українських еміграційних пресових видань міжвоєнного часу та на визначенні ступеню зацікавленості скандинавськими питаннями у колах українців на еміграції в Європі та Америці.

Виходячи з вищесказаного, метою статті є увиразнення образу Шведського королівства як держави добробуту у фокусі періодики української еміграції міжвоєнного періоду. Основними завданнями дослідження є: вивчення архіву тижневика «Тризуб/Le Trident» (Франція) та газети «Свобода/Svoboda» (США) міжвоєнного періоду, віднайдення та аналіз публікацій сучасників про шведську державу добробуту, визначення актуальності зазначених статей у колах українців на еміграції 1925-1939 pp.

Українська еміграція, сформована після поразки Української революції, закономірно піклувалася про випуск власних періодичних видань у містах, що стали осідком українських громад. Однією з актуальних тем, що висвітлювалась на сторінках еміграційних пресових видань упродовж кінця 1920-30-х рр., була Швеція, яка стрімко увірвалася до числа успішних європейських держав і започаткувала процес послідовної розбудови держави загального добробуту.

Охарактеризувати висвітлення шведської держави добробуту на шпальтах української європейської еміграційної преси пропонуємо на прикладі авторитетного тижневика «Тризуб/Le Trident», що виходив у Парижі з 15 жовтня 1925 р. (публікації припинились у 1940 р.). Це був перший часопис українською мовою у Франції. Тижневик виступив «під знаком Тризуба із розумінням того, що логіка розвитку національного руху в Україні веде до повторення подій 1918-1919 рр.». Ініціатива цього видання належала Головному Отаманові Військ і Флоту УНР Симону Петлюрі, державному діячеві та вченому Павлу Чижевському (перше число часопису побачило світ уже після його смерті) та громадському діячеві і публіцисту В’ячеславу Прокоповичу (у 1925-1939 рр. був редактором тижневика «Тризуб»). Як пише видання, «Ще під час їхнього спільного перебування в 1924 р. в Женеві обговорювали вони способи заснування такого журналу, його завдання, гасла, програму. В нашій роботі - проповіді шукання нашої національної сили в єдності, вірності законній народній українській владі і рішучої боротьби з окупантами Української Народної Республіки»3.

У перші роки діяльності «Тризубу» почали з'являтися статті, присвячені темі благоденства Скандинавії, створеного неписаною унією ключових країн регіону. У публікації про держави Балтійського басейну, опублікованій у жовтні 1926 р., йшлося, зокрема, про наступне: «Три давніх скандинавських держави, - Швеція, Норвегія та Данія, - маючи спільні інтереси на Балтійському морі, досить давно вже занехаяли старовинне політичне суперництво одна з одною, виробивши для себе такий modus vivendi, який дає їм можливість спокійно жити, абсолютно не побоюючись якої небудь несподіванки з боку сусіди». Автор наголошував, що налагодження тісних культурних зв'язків між цими країнами лише підсилює самостійний розвиток національних культур, а економічні та торговельні інтереси регулюються «еластичними договорами» 4 .

На думку автора, виникнення такої своєрідної конфедерації нівелювало будь-

з Заташанський І. П’ять років з існування «Тризуба» // Тризуб/ Le Trident. 1930. 15 жовтня. Ч. 39 (247). C. 2.

${ }^{4}$ Observator. Держави Балтійського басейну і СССР // Тризуб/ Le Trident. 1926. 10 жовтня. Ч. 48. C. 4. 
які приводи до війни і створило умови до того, що «...Данія, не дочікуючись, як вирішить Ліга Націй справу обезброєння, обезброїлась торік сама по добрій своїй волі. Зараз вона майже не має ні армії, ні флоти, ні арсеналів, ні військових портів; Норвегія, що-до цього, близька до такого самого стану, а коли Швеція не пішла ще по цій дорозі, то, мабуть, тільки тому, що не дуже далеко од неї знаходиться такий ненадійний сусіда, як СССР, про існування якого вона забувати не сміє, бо дуже вже багато зазнала від його предків»5.

Зауважимо, що автор публікації підкреслив одну з надвагомих обставин, яка сприяла розбудові держави добробуту у Швеції за декілька років потому, - йдеться про успішну практику договірних відносин і політику нейтралітету. Як відомо, нейтральність держави суттєво залежна від географічного положення та політичного становища країни. У 1914 р. на початку Першої світової війни Швеція зробила односторонню офіційну заяву про нейтралітет і дотрималась слова впродовж усіх воєнних років, надаючи медичну допомогу постраждалим країнам, приймаючи біженців тощо. Однозначно, така політика дозволила акумулювати існуючі ресурси та спрямувати їх на внутрішній розвиток країни у подальшому. Тож автор україно-французького тижневика недаремно приділив увагу скандинавському прикладу, який би направду хотілось мати у Чорноморському регіоні, в той час виснаженому військовими та політичними протистояннями.

Відповідно до цілей редакції «Тризуба», українське паризьке видання пильно відстежувало та висвітлювало антирадянські акції європейських держав. У цьому ракурсі Швеція міжвоєнного часу незмінно залишалась зразком упевненої протидії комуністичному СРСР у всіх сферах життя країни. До прикладу, упродовж 1930 р. у тижневику обговорювалася тема антирадянського союзу країн Північної Європи: «У Скандинавських державах за минулий рік помітно посилилася тенденція до взаємного наближення. Тенденція та перестрашила сусідні совіти, і большевицька преса уже кричить на гвалт про утворення скандинавської анти-совітської збройної ліги, на чолі зі шведським королем. До тої Ліги мають, на думку Москви, ввійти крім Швеції, Данія, Норвегія, Фінляндія, Естонія та Латвія»6.

Тривалий час в об'єктиві видання «Тризуб» залишалась історія співробітника радянського посольства у Швеції: «Совітський морський аташе в Стокгольмі Дімітрієвський відмовився їхати до Москви і подав прохання до шведського уряду про дозвіл лишитися у Швеції на становищі емігранта»7. Зауважимо, що на той час набирала обертів чистка радянських дипломатичних корпусів і за терміновим викликом у «центр» зазвичай слідував арешт і розстріл. Підставою до повернення була відповідна постанова ЦВК СРСР листопада 1929 р., що повідомляла: «Особи, які відмовились повернутися до Союзу РСР, оголошуються поза законом». Шведська влада відхилила вимогу видавати дипломата. Дмитрієвський, незважаючи на постійну загрозу його життю, надалі публічно засуджував радянський режим. Як, до прикладу, зазначено у цій замітці: «Бувший большевицький радник у Стокгольмі Дімітрієвський розпублікував у пресі відомості про постачання московським урядом фінським комуністам зброї»8.

\footnotetext{
5 Ibidem.

6 Observator. Баланс за 1929 р. // Тризуб/ Le Trident. 1930. 19 січня. Ч. 3 (211). С. 19; Observator. В зоні лімітрофів // Тризуб/ Le Trident. 1930.9 березня. Ч. 10 (218). С. 21.

73 широкого світу // Тризуб/ Le Trident. 1930. 4 травня. Ч. 18 (226). С. 24.

83 широкого світу // Тризуб/ Le Trident. 1930. 5 жовтня. Ч. 37 (245). С. 27.
} 
Важливим свідченням продуктивної українсько-шведської співпраці став візит членів Військового Товариства до Швеції навесні 1930 р. Йдеться про Товариство б. Вояків Армії УНР у Франції, комбатантську організацію, засновану у 1927 р. в Парижі. Про шведську подорож українських ветеранів дізнаємося зі статті на шпальтах «Тризуба» від 30 березня 1930 р. У ній, зокрема, йшлося про наступне: «3 приводу роковин Полтавського бою Управа Військового Т-ва, згідно бажанню членів його, вирішила покласти вінок на могилу Карла 12, короля Шведського. До цієї акції приєдналися військові організації в Чехії та Румунії та, певно, також сприятливу відповідь буде одержано від вояків, що перебувають в Польщі. Вінок передбачається покласти від армії УНР в вигляді пальмової вітки з національними стрічками 3 написом: "Новітні нащадки незабутнього Гетьмана Івана Мазепи - Карлові XII, Королеві Шведському, союзникові в відвічній боротьбі з Московією”». Також зазначалося, що прихильну відповідь вже надано шведським урядом, а товариство звертається до всіх вояків і громадян із закликом прийти з пожертвами на спорядження почесної делегації9.

Редакція «Тризуба» періодично наголошувала на тому, що «тижневикові за наших днів годі угнатися за бурхливим темпом міжнародніх подій... на нашу долю зістанеться лише спроба уловлювати загальні лінії вказаних подій, порівнювати їх 3 минулим, прикладати до можливих перспектив майбутніх»10. Разом 3 тим, гучні культурні події все ж знаходили відображення на сторінках часопису, зокрема у рубриці «3 широкого світу». До прикладу, з випусків тижневика за 1930 р. ми дізнаємось про те, що «24 квітня Швеція має святкувати 50-тиліття проходу шведського корабля «Вега» вподовж півничних берегів Азії до Японії»11, а «на острові Вен відкрито обсерваторію-музей імени Браге, славнозвісного шведського астронома 16-го віку, що написав відомий трактат про небесну механіку» ${ }^{2}$. Того ж року редакція «Тризуба» повідомляла про шведського дослідника Свен-Гедіна, який «відкрив в пустелі Гобі сліди старовинної стіни подібної до відомої вже китайської стіни»13.

На відміну від європейської української еміграційної преси, яка акцентувала свою увагу на міжнародній діяльності шведського уряду та його антикомуністичних заходах, українці в Америці також широко висвітлювали події культури та шведського способу життя нарівні з темами, згаданими вище. Розглянемо шведську державу добробуту в об’єктиві української еміграційної преси в Америці міжвоєнного періоду на прикладі газети української громади «СВОБОДА/SVOBODA». Це авторитетне щотижневе видання, яке виходить друком з 1893 р. та є першою українською газетою у світі та США (у міжвоєнний час виходила друком у Нью-Джерсі).

Починаючи 31929 р., «шведська тема» періодично актуалізується на сторінках «Свободи». Шведські дані включені до більшості порівняльних зведень різних показників країн-світових лідерів, до прикладу, у питаннях озброєння ${ }^{14}$, кількості безробітних ${ }^{15}$, прожиткового мінімуму16, кількості особистих і вантажних автівок ${ }^{17}$

\footnotetext{
9 Вінок на могилу Карла XII // Тризуб/ Le Trident. 1930. 30 березня. Ч. 13 (221). С. 28.

10 Тризуб/ Le Trident. 1939. 12 лютого. Ч. 6 (656). С. 10.

113 широкого світу // Тризуб/ Le Trident. 20 квітня 1930. Ч. 16-7 (224-5). С. 37.

12 Ibid. C. 36.

133 широкого світу // Тризуб/ Le Trident. 1930. 23 листопада. Ч. 44 (252). С. 28.

14 Розброєння? // Свобода/Svoboda. 1935. 07 березня. С. 4.

15 Скількість безробітних у світі // Свобода/Svoboda. 1931. 28 жовтня. С. 2.

16 Кошти прожитку у ріжних країнах // Свобода/Svoboda. 1929. 28 жовтня. С. 4.

17 Чи ви це знаєте? // Свобода/Svoboda. 1935. 25 лютого. С. 1.
} 
тощо. Вказувалася також порівняльна статистика чисельності кінотеатрів ${ }^{18}$. Цікаво, що для Швеції ця індустрія була одним із інструментів формування щасливої нації через цензурування кінострічок. Такий особливий факт не оминули увагу дописувачі «Свободи» та докладно виклали цей процес наступним: «Швеція була першим на світі краєм, де створили уряд лікаря, як фільмового цензора. Ще 1911го р. Шведське Фільмове Товариство покликало на це місце славного лікаря хворіб нервів, д-ра Гунара Бермана. Лікар-цензор має розглядати вплив, що його викликують поодинокі сцени на нервну систему глядача й евентуально лагодити занадто міцні сцени. Зпочатку відносилися до цього лікаря-цензора з недовірям, але зчасом усі признали його додатню роботу. Рівень шведських фільмів піднісся дуже значно, причім щораз менше продукують тепер фільм, які мають відємний вплив на нервову систему глядачів»19.

У лютому 1929 р. на першій шпальті видання було вміщено замітку під заголовком «Щаслива Швеція». У ній наголошується той факт, що наразі Швеція - «єдина держава на світі, яка свій буджет будує не на підвищенню податків для своїх громадян, а на підвищенню прибутковости своїх підприємств, через що як посередні так і безпосередні податки що року все зменшуються». Автор замітки наголошує, що міністр фінансів Н. Волін презентував на розгляд шведського парламенту бюджет на рік, в якому податки вкотре зменшувались майже на третину. Проєкт бюджету був одразу ж прийнятий, а міністр отримав визнання за послідовну успішну працю20.

У декількох випусках «Свободи» також писали про особливий спосіб боротьби «щасливих шведів» 3 проступками, який полягав у багаторічній турботі уряду про школи та культурний розвиток населення. Автор замітки вважав, що саме в цьому $€$ секрет нестримного зменшення числа арештованих у цій скандинавській країні, адже «...при кінці липня (прим. - 1929 р.) було в цілій Швеції всього дві тисячі арештантів. У вязниці Варберг за останні два роки не сиділо разом більше як по два три вязні. Тепер на цілу вязницю $є$ там один вязень і двох сторожів». Наголошувалось, що спорожнілі в'язниці шведська влада планує використати для корисніших цілей 21 . Припускаємо, що обрана стратегія була цілком успішною, адже у порівнянні з іншими європейськими країнами, низький рівень злочинності у Швеції надалі послідовно зменшувався. Як свідчать дані 1931 р., «звідомлення шведського тюремного департаменту каже, що цього року засуджених у шведських вязницях $€$ 1,984 проти 2,113 у минулому році. Особи, які були засуджені в останніх зимових місяцях, відсиділи радо свої кари. Уряд пояснює це людяною поведінкою в шведських вязницях і соціяльними відносинами»22.

Новини зі Швеції на сторінках «Свободи» явно свідчили про прихильність суспільства до ідей соціал-демократів, які на той час заявили про себе успішними проектами. Так, у випуску газети вересня 1932 р. зазначалось, що чергові вибори «...показали сильний нахил на ліво. Премієром має стати котрийсь із провідників соціалістичної партії»23. Власне, так і сталось. Перемога соціал-демократів на вибо-

\footnotetext{
18 Де найбільше кін? // Свобода/Svoboda. 1937. 1 квітня. С. 2.

19 Фільми і нерви // Свобода/Svoboda. 1936. 30 грудня. С. 1.

20 Щаслива Швеція // Свобода/Svoboda. 1929. 28 лютого. С. 1.

21 Культура найкраще поборює проступок // Свобода/Svoboda. 1929. 29 листопада. C. 1.

22 Шведські вязниці опорожнюються // Свобода/Svoboda. 1931. 17 грудня. С. 3.

23 Переміна кабінету у Швеції // Свобода/Svoboda. 1932. 21 вересня. С. 1.
} 
pax 1932 р. стала безпрецедентним успіхом у європейській історії, а прем'єром обрали лідера шведських соціал-демократів П.А. Ханссона, який став творцем успішної концепції «Дому для народу» («Folkhem») - основи шведської моделі держави загального добробуту.

Успішна реалізація реформ у Швеції вже за декілька років продемонструвала світові високі стандарти урядової політики соціал-демократів і загального добробуту шведського суспільства. Набуло актуальності питання передумов, які сприяли стрімкому розвитку країни. У цьому контексті в 1937 р. на сторінках «Свободи» була вміщена стаття під заголовком «Країна щасливих людей», в якій докладно розповідається про природні багатства Швеції, народні промисли, шведський спосіб життя й ін. Так, автор підкреслює низку ключових факторів, що сприяли успішному розвиткові країни. По-перше, «від 1814 року (Швеція - aвт.) не знала, що це війна, тому могла всю увагу звернути на культурний розвиток». По-друге, нині держава регулює власний ринок праці, зобов'язуючи мігрантів підписувати посвідку про відмову займати у Швеції будь-яке становище, і тому «в тій країні нема безробіття». По-третє, у побуті «видно вплив раціоналізації та стандартизації при виробі предметів щоденної потреби». Автором наголошено на традиціях повсякдення «селянина, міщанина, службовика, торговця», кожен з яких «працює дбайливо і щиро, бо знає що час праці обмежений, та що його після совісно виконаної праці жде відпочинок»24.

Відповідно до тексту статті, вільний час шведи проводять за читанням часописів і книжок, слуханням лекцій, участі у дискусіях, «в яких збільшується їх знання, відпочиває тіло, нагромаджується енергія для завтрашньої праці», яка, до слова, тривала до 5-6 години вечора як в селі, так і у місті. Жителі Швеції міжвоєнного часу описані як веселі, життєрадісні та вдоволені громадяни своєї батьківщини. Як доказ - «...шведи мають навіть пісню, яка кінчиться замітним окликом, що повторюється наче рефрен: Що ми, до чорта зробили, що нам $є$ так добре?»25.

3 погляду сьогодення розуміємо, що ця стаття описала ключовий принцип життя шведів, відомий нам під назвою «lagom» (y пер. - достатній). Шведська держава добробуту створила усі умови для того, аби звичай зберігся до нашого часу, тож сучасні шведи не уявляють свого життя поза гармонією Лагом, керуючись девізом «Lagom är bäst», що значить «У міру - найкраще за все».

Важливо, що цей принцип гармонії мав міцне коріння у шведській народній культурі, яка плекала любов до оточення, єдність з природою та простоту побуту. Міцним фундаментом для збереження традиційної культури та її широкої популяризації став перший у світі Скансен - музей народного побуту під відкритим небом. Звісно ж, українські читачі на еміграції не оминули увагою вісті про таку унікальну культурну установу. Ґрунтовна стаття про природний музей починалась словами: «Хто не бачив Скансену, не бачив усієї Швеції», бо природний музей Скансен, часть північного музею у Стокгольмі, зі своїми до того музею перенесеними цілими хуторами (господарствами), хатами, внутрішнім уладженням, господарським знаряддям, причандалами й іншими культурними предметами 3 типічних провінцій країни, - $є$, як сказано, зборищем шведської культури в мініятурі. Скансен $є$ одиноким у свойому роді у всій Европі»26.

\footnotetext{
24 Країна щасливих людей // Свобода/Svoboda. 1937. 14 червня. С. 4.

25 Ibidem.

26 Скансен символ шведської нац. Культури // Альманах УНС. 1931. С. 158-159.
} 
Ідея створення такого «домашнього» музею на «околиці для того дуже підхожій, в Дюргардені біля Стокгольму», належала культурологу д-ру Артуру Газеліюсу, також засновнику знаменитого Скандинавського музею (Nordiska Museet) в Стокгольмі. Зазначалось, що «Скансен не є лише етнографічним і культурно-історичним музеєм на вільній природі, а також рівночасно забавовим парком. Там танцюють старі народні танці у шведській народній околиці, а також сходяться великоміщани зі Стокгольму, коли нарід на селі святкує старі звичаї. ...Куди лише оглянешся, всюди побачиш шведську землю, яку замешкує нарід, котрий мав свою культуру ще в переісторичних часах. Скансен $є$ гарним символом того»27, - резюмував автор.

Ще одним свідченням урядової підтримки гуманітарної сфери у Швеції, описаним у «Свободі», є діяльність Товариства ім. Карла XII, очолюваного директором державних архівів, д-ром Альмквістом. Він, за словами сучасників, будучи особою надзвичайно енергійною, з великою історичною ерудицією та знанням Східної Європи, вміло керував виданням наукових збірників, присвячених добі Карла XII, в яких чинне місце займали публікації про І. Мазепу, П.Орлика та про Україну XVIII ст. в цілому. Важливо зазначити, що на той час Карл XII був одним із найбільш шанованих монархів у шведській історії, хоч і мав таку ж незчисленну армію критиків. Автор статті підкреслює, що «...Цей самий факт показує, яку велику, але і яку трагічну ролю відіграв Карло XII у шведській історії. Та не тільки в шведській, але і в нашій. Невдача плянів Карла XII на довгі роки припечатала долю України»28.

Переоцінку цієї, без перебільшення, знакової історичної постаті автор статті небезпідставно приписував вже згаданому Товариству ім. Карла XII, заснованому ще у 1910 р. У публікації наголошується на тому, що «...Першим завданням поставило собі товариство прослідкувати всебічно та всесторонньо не тільки всі подвиги Карла XII та його невдачі, але й усі побічні політичні моменти того періоду. Шведські історики, члени того товариства, створили нову історичну школу. Попри історичні досліди та публікації поставило собі товариство також за ціль, повільно, але систематично перевиховати шведську націю, опираючись при тому на культурі й традиціях Карла XII. ...Знайдено нову оцінку і тодішніх сусідів Швеції, в першу чергу Москви, як теж і приятелів Карла XII, себто Мазепи та його наслідника Орлика»29.

Окремо автор підкреслив і той факт, що очевидно, саме з часів Карла XII спостерігається «...намагання шведів заховувати нейтральність у всіх міжнародних ускладненнях і шукання миру навіть ціною втрати території». Поширення переконання про те, що «...Карло XII не ради заспокоєння своїх амбіцій кинувся був у нерівний бій із Москвою і, не маючи сам політичних спосібностей, наразив Швецію на великі втрати» ${ }^{30}$ сприяло поширенню думки, що його походи були диктовані життєвими інтересами шведської нації, і він перший зрозумів загрозу для Швеції з боку Москви.

Пишний 25-літній ювілей Товариства ім. Карла XII засвідчив необхідність існування такого товариства, адже, зі слів автора, «...є воно для Швеції потрібне головно в тому часі, коли нова Московія простягає свої руки на захід, зокрема на Скандинавський Півостров»31.

\footnotetext{
27 Ibidem.

28 Карло XII і сучасна Швеція // Свобода/Svoboda. 1936. 02 травня. С. 3.

29 Ibidem.

30 Ibidem.

31 Ibidem.
} 
Тема взаємин з Москвою (вже у XX ст.) не сходила зі сторінок газети «Свобода», яка, на рівні з європейськими українськими пресовими редакціями, завжди займала активну антикомуністичну позицію. У вересні 1930 р. газета опублікувала замітку «Спосіб на комуністів». У ній йшлося про прийом, яким Швеція позбувалася прихильників комунізму в країні. «Шведський уряд вислав усіх своїх комуністів на 3 роки до СРСР: навіть виплачував їм кошти подорожі та платню на 3 місяці, заки найдуть працю в радянських републиках. Шведські націоналісти переконані, що кожний комуніст, пробувши 3 роки під владою большевиків, верне до Швеції ворогом комунізму». При цьому редакція газети підкреслювала про суголосність прийому із оприлюдненим раніше у фейлетоні «Діла», де йшлося про бажання посилати «наших комуністів» за Збруч, а навзаєм забирати українських націоналістів 3 радянської України. Мабуть, «шведський націоналістичний табор послухав Галактіона Чіпки», припускає автор 32 .

Пересторога Швеції щодо СРСР систематично обговорювалась на сторінках українсько-американського видання у 1935-39 рр. До прикладу, це стосувалося фінансових операцій, коли шведський уряд повідомив про те, що «...не ставиться вже прихильно до позичок, які шведські промисловці уділюють Совєтам. Каже, що коли хто хоче позичати, то хай це робить на власне ризико» ${ }^{33}$. Або ж, коли йшлося про посилене курсування радянських суден у морському просторі країни та регіону: «Совєти звернулись до Норвегії, Швеції й Данії, щоб вони винаймили їм вантажні кораблі для перевозу товарів, головно дерева, до - Англії через Арктику. Норвегія вже дала на це згоду. Совєти виправдовують це тим, що возити товари через Балтійське і Північне море тепер небезпечно. Цікаве й те, що Совєти намагаються дуже скорого вирішення. Покищо Швеція і Данія отягаються з відповіддю»34.

Незважаючи на нейтральний статус Швеції у військових конфліктах, країна послідовно реформувала військову оборонну сферу, особливо в умовах наростання напруги 1930-х рр. з боку СРСР. Так, у замітках на сторінках «Свободи» фіксуємо наступні кроки, зокрема у сфері повітряних сил. По-перше, у 1935 р. «Спеціяльна комісія покінчила п’ять-літні студії над оборонними засобами Швеції і предложила урядови цілий плян конечних перемін. На перше місце поставила комісія розбудову повітряної фльоти і збільшення числа офіцирів армії»35. По-друге, за декілька років за вигідних фінансових пропозицій Швеція збільшила кількість військових одиниць на озброєнні війська. Зокрема, йдеться про знесення ембарга на зброю у США, внаслідок чого «...чужі держави почали поспішно робити в Америці величезні закупи ріжних воєнних продуктів. Найбільше замовляють літаків, бо є вже тепер замовлень на 7,800 літаків. Замовили їх: Франція, Англія, Бельгія, а навіть Швеція замовила 250 воєнних літаків. Крім того, замовляють величезні скількості інших продуктів, моторів, мотоциклів, авт, харчів, одежі, медикаментів, радіоапаратів і т.п. Сподіваються замовлень впродовж кількох наступних тижнів на біліон долярів»36.

На наш погляд, у першу чергу агресія СРСР прискорила інтенсивність підготовки у військовій оборонній сфері Швеції. Преса листопада 1939 р. повідомляла про

\footnotetext{
32 Спосіб на більшовиків // Свобода/Svoboda. 1930. 27 вересня. С. 1.

33 Не хочуть ризикувати // Свобода/Svoboda. 1936. 20 травня. С. 1.

34 Новий совєтський «трик» // Свобода/Svoboda. 1939. 06 жовтня. С. 1.

35 Швеція потребує сильнішої оборони // Свобода/Svoboda. 1935. 29 серпня. С. 1.

36 Нижча палата конгресу теж відкидає ембарго // Свобода/Svoboda. 1939. 4 листопада. С. 1.
} 
наступне: «Данія, Швеція, Норвегія і Фінляндія зажаховані советським наступом на балтійські держави. Та, не зважаючи на загрозу, поступатимуть дуже обережно, щоб заховати повну невтральність. Можливо, що виступлять навіть разом з іншими невтральними державами з якоюсь мировою пропозицією. На це натискає дипльоматично Німеччина, даючи до пізнання, що як буде замирення, то вона не допустить до совєтського наступу на скандинавські держави. Та біда, що ті держави не мають довіри до Совєтів, ні до Гітлєра»37.

Лише пряма загроза військового вторгнення з боку СРСР змусила шведський уряд вдатися до рішучих дій з оборони власних кордонів, хоч все ж зі збереженням нейтрального статусу у світовому конфлікті, що зачинався. «Не зважаючи на совєтський наступ на цілому фронті, яким розпочали Совєти ґенеральну офензиву в Фінляндії, їхні війська вдержались в двох місцях на занятих позиціях. ...Ведуться переговори, щоб довести край до цілковитого обєднання з огляду на небезпеку війни з Совєтами. Буде створений між партійний міністерський кабінет, щоб усіх задоволити. Покликано 40,000 нових жовнірів. Край, що нормально має всього 20,000 війська, тепер має армію з 150,000 жовнірів, яку постійно збільшує. Швеція замкнула також Ботнійський залив для совєтських кораблів»38. Зауважимо, що Швеція все ж витримала умовний статус нейтралітету в роки Другої світової війни, керуючись принципом «подвійних стандартів» та утримуючи ресурс для забезпечення базового рівня добробуту населення. Завдяки цьому, згодом, у 1950-х рр. настане золота епоха держави добробуту в країні, а термін «шведська модель» стане економічним зразком для всього світу.

Отже, за результатами вивчення архіву тижневика «Тризуб/Le Trident» (Франція) та газети «Свобода/Svoboda» (США) міжвоєнного періоду - авторитетних українських еміграційних видань того часу, фіксуємо, що в загальному держава добробуту у Швеції була зразковим кейсом і предметом обговорення в українській еміграційній пресі міжвоєнного часу, яка періодично висвітлювала новини з політичного, економічного та культурного життя країни. У процесі опрацювання архіву зазначених видань виявили наступна закономірність: редакцію європейської газети значно більше цікавила міжнародна ситуація у Балтійському регіоні та зовнішньополітична діяльність шведського уряду, аніж суспільні питання в країні. Цим вона відрізнялась від української газети у США, яка активно обговорювала повсякденне життя шведів, їх здобутки у гуманітарній сфері на рівні з питаннями загальноєвропейського значення. Розуміємо, що українці на еміграції у 1926-1939 рр. на сторінках власних пресових видань поділяли цінності демократичного шведського суспільства, схвалювали успішну програму соціальних реформ, визнавали необхідність звернення до історичного минулого країн у контексті актуальних викликів, підтримували антикомуністичну діяльність в країні та поза її межами.

\section{REFERENCES}

Koval, O. (2020). Shvedska derzhava dobrobutu v ukrainskii emihratsiinii presi mizhvoiennoho periodu (na prykladi hazety «Svoboda», SShA) [Swedish welfare state in the Ukrainian emigration press of the interwar period (on the example of the newspaper «Svoboda», USA)]. Proceedings of the Conference: Suspilni nauky: vyklyky i sohodennia (Odesa, Ukraina, 12-13 chervnia 2020 r.). Odesa. P. 24-29 [in Ukrainian].

Koval, O. \& Kravchenko, P. (2021). Shvedske politychne ta kulturne zhyttia na shpaltakh ukrainskoi

37 Скандинавський бльок // Свобода/Svoboda. 1939. 20 жовтня. С. 1.

38 Швеція готується до війни // Свобода/Svoboda. 1939. 07 грудня. С. 1. 
emihratsiinoi presy mizhvoiennoho chasu (na prykladi tyzhnevyka «Tryzub/Le Trident», Frantsiia) [Swedish political and cultural life in the columns of the Ukrainian emigration press of the interwar period (on the example of the weekly «Le Trident», France)]. Proceedings of the Conference: The IV International Science Conference «Prospects and achievements in applied and basic sciences» (February 9-12, 2021, Budapest, Hungary). Budapest. P. 193-196 [in Ukrainian].

Zatashanskyi, I. (1930, October 15). P'iat rokiv z isnuvannia «Tryzuba» [Five years since the existence of «Trident»]. Tryzub/ Le Trident, 39 (247), 2 [in Ukrainian].

\section{Olesia Koval}

(Vinnytsia Mykhailo Kotsiubynskyi State Pedagogical University, Vinnytsia, Ukraina)

e-mail: koval.vinhistory@gmail.com

ORCID: https://orcid.org/0000-0002-0703-6490

\section{Swedish State of Well-Being in Focus of Ukrainian Emigration Periodics of Interwar Period}

State of well-being in Sweden (economic, political, military, and humanitarian areas) was reflected in the Ukrainian emigration press of 1926-1939. Stated theme is a fresh look at the issues of Ukrainian-Swedish relations during the interwar period. The goal of the paper is to clarify the image of the Kingdom of Sweden as a state of well-being in the focus of Ukrainian emigration periodicals during the interwar period. The archives of the weekly 'Trident/Le Trident' (France) and the newspaper 'Freedom/Svoboda' (USA) of the interwar period are analyzed in the study, the publications of contemporaries about the Swedish state of wellbeing are monitored, and the relevance of articles under review among Ukrainian emigrants in 1925-1939 is determined.

Ukrainian emigration press in Europe is represented by the weekly 'Trident/Le Trident', which was the first Ukrainian publication in France and systematically published news in accordance with the publication's priorities. Among those were defending national interests, counteractions against Soviet crimes, anti-Soviet European sanctions, the success of social and democratic governments, and so on. Sweden always remained a standard of resolute opposition to the communist regime of the USSR in all spheres of life, so it received comprehensive support and active positioning in the columns of the Ukrainian Parisian weekly.

Ukrainian emigrants in America familiarized themselves with the Swedish experience in the pages of 'Freedom/Svoboda' (USA), the oldest Ukrainian newspaper in the world. The publications repeatedly emphasized the support of the Social Democrats by the population in Sweden, the successful reforms of the interwar socialist government, which managed to eliminate unemployment, stop mass emigration of Swedes abroad, and strengthen the country's economy during the global economic crisis. We also see the newspaper editorial staff's, and therefore the Ukrainian community of which it was the official herald, outspoken favor to Swedish life and the successive consecutive reforms of the national government.

To conclude, it is necessary to say that the state of well-being in Sweden was an exemplary case and the subject of discussion in Ukrainian emigration press of the interwar period. In 1925-1939, Ukrainian emigration shared the values of a democratic Swedish society in its press, approved a successful program of social reforms, recognized the need to address the state's historical past in the context of current challenges, and supported anti-communist activities inside the state and abroad.

Keywords: state of well-being, Sweden, Trident, Svoboda, Ukrainian emigration 